\title{
BAGAIMANA REAKSI INVESTOR TERHADAP CORPORATE SOSIAL DISCLOSURE (CSD)? (Studi pada Perusahaan Pemenang Indonesia Most Trusted Companies Award)
}

\author{
Devica Pratiwi ${ }^{1}$, Kezia Josephine ${ }^{2}$ \\ IProgram Studi Akuntansi, Univesitas Bunda Mulia, Jakarta, dpratiwi@bundamulia.ac.id \\ ${ }^{2}$ Program Studi Akuntansi, Univesitas Bunda Mulia, Jakarta, kjosephine@bundamulia.ac.id
}

\begin{abstract}
ABSTRAK
Perusahaan melaksanakan kegiatan CSR dapat dikelompokkan pada tiga motif, seperti: motif keuangan (financial motive), motif etika (ethic motive), dan motif altruistic (altruistic motive). Ketiga motif ini adalah dasar perusahaan dalam merencanakan kegiatan CSR mereka tiap tahunnya. Setiap motif yang dijalankan tentunya memiliki tujuan yang berdampak baik bagi segi ekonomi dan sosial perusahaan. Citra perusahaan yang menjadi baik pada akhirnya memperoleh kepercayaan di mata publik, akan berpengaruh positif pada sisi keuangan perusahaan dan saham perusahaan.

Penelitian ini akan berfokus pada pengungkapan CSR (CSD) berdasarkan motif perusahaan dan memeriksa pengaruhnya terhadap kinerja keuangan perusahaan berdasarkan pengukuran pasar, dilihat dari reaksi investor yang diproksikan dengan return saham. Penelitian ini menggunakan 56 laporan tahunan perusahaan tahun 2013 sampai dengan 2016, yang terdaftar dalam "Indonesia Most Trusted Companies Awards" yang secara lengkap dipublikasikan pada tahun 2014 sampai dengan tahun 2017 oleh Majalah SWA.

Metode analisis statistik dalam penelitian ini menggunakan moderated regression analysis, di mana variabel independen berupa corporate social disclosure (CSD) menggunakan motif keuangan, etika dan altruistik. Sedangkan variabel dependen berupa Corporate Finansial Performance (CFP) berdasarkan pengukuran pasar yang diproksikan melalui return saham.

Hasil penelitian menunjukkan bahwa corporate social disclosure (CSD) berdasarkan motif keuangan (financial motive) memberikan pengaruh terhadap tingkat return saham, sedangkan CSD denganmotif etika (ethic motive) dan motif altruistic (altruistic motive) belum dapat memberikan bukti yang memadai untuk mempengaruhi tingkat return saham.
\end{abstract}

Kata Kunci: CSD, CFP, Motif CSR 


\title{
National Conference of Creative Industry: \\ Sustainable Tourism Industry for Economic Development
}

Universitas Bunda Mulia, Jakarta, 5-6 September 2018

e-ISSN No: 2622 - 7436

\begin{abstract}
Companies carrying out CSR activities can be grouped into three motives, such as: financial motive, ethical motive and altruistic motive. These three motives are the foundation of the company in planning their CSR activities each year. Each motive course has a purpose that has a good impact on the economic and social aspects of the company. A good corporate image ultimately gained public's trust and will have a positive effect on the financial side of the company and the company's stock.
\end{abstract}

This research will focus on CSR disclosure (CSD) based on company's motive and check its effect on company's financial performance based on market measurement, seen from investor reaction proxied with stock return. This study uses 56 company annual reports from 2013 to 2016, listed in the "Indonesia Most Trusted Companies Awards" which are fully published in 2014 until 2017 by SWA Magazine.

The method of statistical analysis in this study using moderated regression analysis, where independent variables of corporate social disclosure (CSD) using financial, ethical and altruistic motives. While the dependent variable in the form of Corporate Financial Performance (CFP) based on market measurements proxied through stock return.

The result of the research shows that corporate social disclosure (CSD) based on financial motive gives effect to stock return, while CSD with ethic motive and altruistic motive can't provide sufficient evidence to influence the rate of return stock.

Keywords: CSD, CFP, CSR, CSR Motive

\section{PENDAHULUAN}

Dalam era persaingan ekonomi yang semakin ketat, menjadi suatu keharusan bagi perusahaan untuk mengevaluasi kinerja serta menjalankan strategi perbaikan. Hal ini bertujuan agar perusahan dapat tetap tumbuh dan bersaing. Implementasi perbaikan tidak hanya cukup untuk dilakukan sekali saja namun, harus dilaksanakan secara terus-menerus agar kinerja keuangan perusahaan (Corporate Financial Performance-CFP) menjadi semakin baik dan tetap unggul dalam persaingan yang ada. Oleh sebab itu, untuk memenuhi tujuan utama perusahaan diperlukan pengukuran kinerja yang mengambarkan aktivitas serta prestasi perusahaan.

Pengukuran kinerja merupakan faktor yang sangat penting bagi perusahaan untuk menilai perusahaan dan merencanakan keputusan di masa mendatang. Hal ini dilakukan untuk mencapai efisiensi dan efektivitas pada seluruh bisnis perusahaan. CFP dapat tercermin melalui return dari peningkatan nilai pasar harga saham perusahaan tersebut. Sering kali dikatakan apabila harga saham perusahaan meningkat maka kemakmuran investor juga akan meningkat. Hal ini dikarenakan peningkatan harga saham akan meningkatkan return investasi milik investor. Ketika perusahaan mampu menawarkan return yang tinggi, maka hal tersebut mampu menarik minat investor untuk menanamkan modalnya dalam perusahaan tersebut. Namun disisi lain jika dikaitkan dengan Legitimacy Theory, perusahaan harus mampu meningkatkan kepercayaan publik tidak hanya melalui CFP saat ini namun juga di masa yang akan datang melalui keselarasan kegiatan operasional entitas. (Riadi, 2017). Kegiatan tanggung sosial perusahaan atau yang dapat dikenal dengan istilah CSR (Corporate Social Responsibility) 


\section{National Conference of Creative Industry: \\ Sustainable Tourism Industry for Economic Development}

Universitas Bunda Mulia, Jakarta, 5-6 September 2018

e-ISSN No: 2622 - 7436

mulai dikembangkan untuk lebih menyentuh masyarakat, tidak sebatas aspek kognisi saja melainkan menyentuh ranah afeksi karena perusahaan yang baik tidak hanya memburu keuntungan ekonomi belaka (profit), melainkan pula memiliki kepedulian terhadap kelestarian lingkungan (planet), dan kesejahteraan masyarakat (people) atau yang lebih dikenal dengan triple bottom line. Perusahaan harus dapat memadukan antara keuntungan ekonomis dengan kentungan sosial dalam praktik bisnisnya. Secara ekonomis, perusahaan berusaha meraih keuntungan sebagai bagian dari motivasi alamiahnya (bisnis). Sementara itu secara sosial, perusahaan juga harus memberikan dampak yang menguntungkan kepada masyarakat sehingga keberadaannya mendapat legitimasi secara sosial. Kepedulian sosial perusahaan didasari alasan bahwa kegiatan perusahaan membawa dampak for better of worse, bagi kondisi lingkungan dan sosial ekonomi masyarakat, khususnya di sekitar perusahaan beroperasi. Pengungkapan kegiatan CSR perusahaan pada laporan tahunan memberikan suatu sinyal positif bahwa perusahaan memang peduli terhadap kesejahteraan masyarakat dan ikut berperan aktif dalam memberikan kehidupan yang lebih baik. Hal ini menumbuhkan citra yang baik (good image) perusahaan yang menarik minat para calon investor, karena pada umummnya perusahaan yang memiliki citra baik dan kepercayaan dari masyarakat, maka memiliki umur yang lebih panjang. Hal itulah yang diharapkan investor pada saat melakukan investasinya, dengan harapan perusahaan selalu berkembang dan dapat bertahan dalam jangka waktu yang panjang.

Empiris menunjukkan bahwa eksekutif termotivasi untuk melakukan kegiatan CSR oleh motif keuangan, karena CSR telah menunjukkan dapat meningkatkan profitabilitas korporasi (Orlitzky et al 2003; Van Beurden dan Gossling 2008). Selain itu, motif intrinsik juga dapat mendorong CSR. Eksekutif dapat memperoleh kenikmatan pribadi dari CSR, yaitu memiliki keprihatinan altruistik atas kesejahteraan orang lain, atau mungkin menganggap CSR sebagai kewajiban moral yang harus mereka amati (Bronn dan Vidaver-Cohen 2009).Penelitian sebelumnya juga menemukan bukti bahwa ada hubungan positif antara corporate social performance (CSP)dan CFP (Dunn \& Sainty, 2009). Selain itu, ditemukan juga hasil bahwa CSD secara signifikan mempengaruhi CFP (Khlif, Guidara, \& Souissi, 2015), dengan pengukuran rasio profitabilitas (Giannarakis, Konteos, \& Sariannidis, 2014). Penelitian yang lain juga membuktikan semakin luasnya pengungkapan CSR, maka akan menarik perhatian investor yang pada akhirnya akan memberikan nilai tambah bagi investor untuk melakukan investasi, sehingga memberi pengaruh pada harga saham (Wang \& Li, 2016). Akan tetapi ditemukan pula bahwa CSD berpengaruh signifikan negatif terhadap CFP (Karagiorgos, 2010). Bahkan ditemukan hasil penelitian CSD tidak memberikan pengaruh signifikan terhadap CFP (Vandevelde, et al., 2014).

Berdasarkan hasil penelitian terdahulu yang telah dijelaskan di atas, maka penelitian yang akan dilakukan berkaitan mengenai pentingnya kewajiban perusahaan melakukan CSD dalam laporan tahunan (annual report), dengan harapan dapat membuktikan bahwa pengungkapan CSR (CSD) dapat mempengaruhi secara positif kinerja keuangan perusahaan (CFP).

\section{TINJAUAN PUSTAKA}

\section{Teori Legitimasi}

Teori legitimasi didasarkan pada gagasan tentang 'kontrak sosial', yang membatasi kegiatan organisasi dalam batas-batas yang ditetapkan oleh masyarakat (Gray, Owen, \& Adams, 1996). Pada dasarnya, organisasi akan memperoleh dukungan dari para pemangku kepentingan dan 


\section{National Conference of Creative Industry: \\ Sustainable Tourism Industry for Economic Development}

Universitas Bunda Mulia, Jakarta, 5-6 September 2018

e-ISSN No: 2622 - 7436

melanjutkan kegiatan sejauh kegiatannya memberikan manfaat, atau setidaknya tidak merugikan masyarakat. Menurut teori ini, organisasi terus berusaha untuk memastikan bahwa kegiatan operasional mereka masih dalam batas-batas dan norma-norma masyarakat masingmasing, yaitu dengan berusaha untuk memastikan bahwa kegiatan mereka dirasakan oleh pihak luar sebagai suatu hal yang 'sah/legitimasi'. Dalam literatur akuntansi sosial dan lingkungan, banyak peneliti setuju bahwa pengungkapan CSR dapat digunakan oleh sebuah organisasi untuk mengurangi ancaman legitimasi dan mengurangi kesenjangan legitimasi (Chen, Patten, \& Roberts, 2008; Deegan, Rankin, \& Voght, 2000; Deegan, Rankin, \& Tobin, 2002). Oleh karena itu, teori legitimasi seolah menyiratkan bahwa manajemen puncak dari suatu organisasi yang bertanggung jawab untuk mengenali kesenjangan legitimasi dan melaksanakan praktekpraktek sosial yang diperlukan. Dengan demikian perusahaan, khususnya struktur tata kelola internal memungkinkan untuk memainkan peran penting dalam mengurangi kesenjangan legitimasi melalui diperpanjang pengungkapan CSR (Khan, Muttakin, \& Siddiqui, 2013).

\section{Konsep Triple Bottom Line}

Paradigma baru perusahaan yang dianggap tumbuh dan berkelanjutan (growth \& sustainable company) saat ini tidak hanya diukur dari pencapaian laba (profit) saja, namun juga diukur dari kepeduliaannya terhadap lingkungan sekitar, baik terhadap komunitas lokal, masyarakat luas, maupun lingkungan hidup. Laporan suatu perusahaan yang menggunakan triple bottom line, selain melaporkan aspek keuangan juga melaporkan aspek kepedulian sosial dan upaya pelestarian lingkungan (Rusdianto, 2013, pIX). Menurut pendapat Carol (1979) yang dikutip oleh Rusdianto (2013) dalam bukunya, berkenaan dengan hal tersebut, maka muncullah triple bottom line model, yang terdiri dari profit, people, \& planet (3P).

- Profit. Perusahaan tetap harus berorientasi untuk mencari keuntungan untuk dapat terus beroperasi dan berkembang.

- People. Perusahaan dalam hal ini harus memiliki kepedulian terhadap kesejahteraan manusia.

- Planet. Pentingnya perusahaan peduli terhadap lingkungan hidup dan keberlanjutan keanekaragaman hayati.

\section{Motivasi CSR}

Menurut Radyati (2014), perilaku perusahaan terhadap CSR dapat dihubungkan dengan beberapa teori motivasi, yakni motivasi intrinsik (normatif) dan motivasi ekstrinsik (instrumental). Motivasi intrinsik mendorong seseorang/perusahaan membahagiakan orang lain karena kepuasan dan kebahagiaan bagi diri sendiri. Jadi ada suatu ikatan emosi untuk meningkatkan kesejahteraan orang lain. Dan konteks perusahaan, "orang lain" adalah para pemangku kepentingan. CSR yang dilakukan berdasarkan motivasi instrumental (ekstrinsik), menurut Waddock \& Graves (1997) dan Orlitsky et al (2003) dapat meningkatkan kinerja keuangan, mengurangi risiko, meningkatkan reputasi, serta meningkatkan komitmen karyawan dan produktivitas. Pada akhirnya, CSR bermotivasi ekstrinsik ini dapat meningkatkan harga saham perusahan. Jadi, CSR digunakan sebagai instrument untuk mendapat imbalan berupa keunggulan bisnis perusahaan.

Sedangkan menurut Lantos (2001), menyarankan tiga jenis CSR: etika, altruistik, dan strategis. CSR etika secara moral wajib dan melampaui pemenuhan kewajiban ekonomi dan hukum perusahaan, terhadap tanggung jawab etisnya untuk menghindari bahaya atau cedera sosial, bahkan jika bisnis tersebut mungkin tidak mendapatkan manfaat dari ini. Oleh karena itu, 


\section{National Conference of Creative Industry: \\ Sustainable Tourism Industry for Economic Development}

Universitas Bunda Mulia, Jakarta, 5-6 September 2018

e-ISSN No: 2622 - 7436

perusahaan secara moral bertanggung jawab kepada individu atau kelompok mana yang mungkin menimbulkan cedera aktual atau potensial (fisik, mental, ekonomi, spiritual, dan emosional) dari tindakan tertentu.

\section{Penelitian Terdahulu}

Penelitian ini disusun berdasarkan hasil penemuan penelitian terdahulu yang telah dikumpulkan untuk mendukung tersusunnya latar belakang, teori pendukung, dan hipotesis penelitian. Pengungkapan CSR atau yang dapat disingkat CSD telah diteliti pada perusahaanperusahaan untuk melihat keterkaitannya dengan kinerja keuangan perusahaan. Khlif, Guidara \& Souissi (2015) melakukan penelitian menggunakan variabel independen berupa pengungkapan sosial dan lingkungan (environmental and social disclosure), sedangkan nilai perusahaan dan ROA digunakan sebagai variabel dependen yang mewakilkan kinerja keuangan perusahaan (corporate financial performance). Hasil yang diperoleh dari penelitian tersebut adalah bahwa keberadaan pengungkapan sosial dan lingkungan perusahaan memiliki pengaruh yang positif signifikan terhadap kinerja keuangan perusahaan untuk Negara Afrika Selatan dan berpengaruh negatif pada kinerja keuangan perusahaan di Negara Morocco.

Penelitian yang dilakukan oleh Wang \& Li (2016), menemukan bahwa semakin luas pengungkapan CSR maka akan memberikan nilai tambah bagi investor untuk melalukan investasi, sehingga hal ini akan memberikan pengaruh terhadap return saham perusahaan. Hal ini sejalan dengan penelitian yang dilakukan oleh Isnalita dan I Made Narsa (2017) yang menemukan bahwa semakin luas CSD maka semakin tinggi nilai saham perusahaan yang dijadikan sebagai indikator dalam mengukur customer loyalty.Penelitian ini juga merupakan penelitian lanjutan yang telah diteliti oleh Pratiwi (2015) mengenai pengaruh CSD terhadap CFP dengan pengukuran Accounting Based Measure. Penelitian ini menemukan bahwa CSR Cost dalam motif etika memiliki pengaruh signifikan terhadap CFP.

\section{Desain Penelitian}

Setiap perusahaan, khususnya yang telah go public diharuskan melakukan kegiatan sosial kepada masyarakat atau lingkungan alam sebagai suatu wujud tanggung jawab mereka karena penggunaan lahan perusahaan/pabrik dan pemanfaatan sumber daya alam dalam proses produksi. Perusahaan yang secara rutin melakukan kegiatan CSR dari tahun ke tahun secara kontinu bertujuan untuk meningkatkan citra perusahaan dihadapan publik, khususnya kepada calon investor dan mendapat kepercayaan masyarakat umum sebagai calon konsumen perusahaan. Biasanya, seorang investor dan calon investor lebih memilih untuk berinvestasi kepada perusahaan yang minim akan konflik hukum dengan masyarakat. Masyarakat juga lebih menghargai perusahaan yang memperhatikan mereka dalam sisi ekonomi, contohnya peminjaman modal UMKM, perbaikan sarana dan prasarana di wilayah masyarakat, atau ikut serta dalam peningkatan kesejahteraan kesehatan dan kemakmuran masyarakat.

Sehingga pada akhirnya, perusahaan yang telah melakukan kegiatan CSR kemungkinan besar akan meningkatkan pendapatan operasional mereka dari penjualan produk kepada masyarakat, bila mampu menarik simpati masyarakat. Perusahaan juga akan mendapatkan investasi besar dari calon investor sehingga mungkin saja harga saham perusahaan meningkat seiringnya membaiknya citra perusahaan di hadapan publik.Penelitian yang dilakukan oleh Johan Graafland (2012) dalam penelitian "Motive for Social Responsibility" yang membukti bahwa kegiatan CSR yang dipengaruhi faktor intrinsik memiliki pengaruh yang signifikan terhadap 
kinerja keuangan perusahaan. Dilanjutkan penelitian oleh Lantos (2001) mengenai "The Ethical of Altruistic Corporate Social Responsibility" yang memberikan pendapat mengenai motif altruistik perusahaan dalam melakukan CSR dikatakan kurang baik karena melanggar hak investor dan tindakan Berdasarkan hasil penelitian tersebut, maka hipotesis yang dibentuk dalam penelitian ini adalah:

H1 : Terdapat pengaruh CSD berdasarkan motif Keuangan (CSD-F) terhadap Corporate Financial Performance - Market Based Measure

H2 : Terdapat pengaruh CSD berdasarkan motif etika (CSD-E) terhadap Corporate Financial Performance - Market Based Measure.

H3 : Terdapat pengaruh CSD berdasarkan motif altruistik (CSD-A) terhadap Corporate Financial Performance - Market Based Measure.

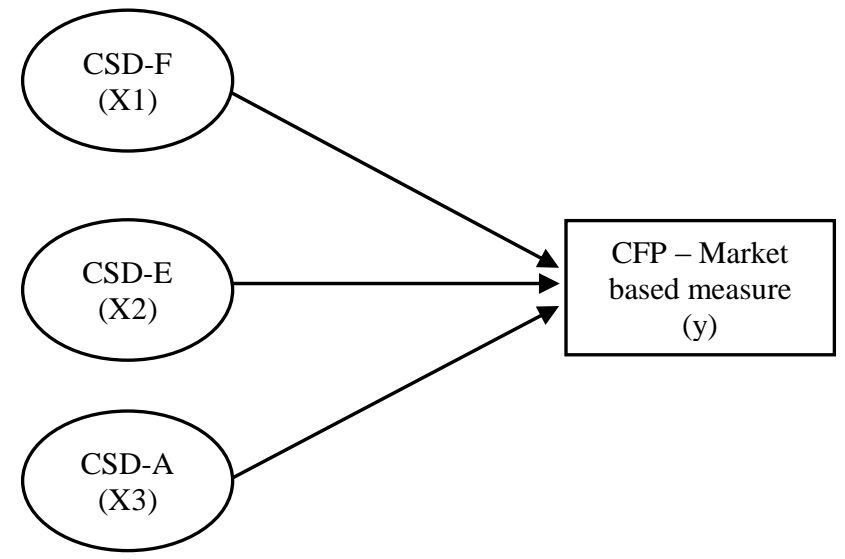

Gambar 1. Rerangka Konseptual

Sumber: Hasil Olahan

\section{METODE PENELITIAN}

Sampel yang digunakan dalam penelitian ini adalah laporan tahunan perusahaan-perusahaan yang terdaftar dalam program "Indonesia Most Trusted Companies Awards" yang secara lengkap dipublikasikan dan dapat diunduh pada tahun 2014 sampai dengan tahun 2017. Perusahaan-perusahaan yang ikut serta, dinilai berdasarkan kinerja keuangan pada tahun sebelumnya, misalkan program Indonesia Most Trusted Companies Awards 2014, melakukan penilaian atas kinerja perusahaan pada tahun 2013. Sehingga sampel data yang digunakan dalam penelitian ini adalah laporan tahunan perusahaan pada tahun 2013 sampai dengan tahun 2016.

\section{Variabel Dependen}

Return saham adalah hasil keuntungan (capital gain) atau hasil kerugian (capital loss) yang diperoleh dari hasil investasi atau trading saham dalam kurun waktu tertentu. Legiman (2015) berpendapat bahwa return saham merupakan hasil yang diperoleh dari investasi. Harapan untuk memperoleh return juga terjadi dalam asset financial. Suatu asset financial menunjukkan kesediaan investor menyediakan sejumlah dana pada saat ini untuk memperoleh sebuah aliran dana pada masa yang akan datang sebagai kompensasi atas faktor waktu selama dana ditanamkan dan risiko yang ditanggung. Dengan demikian para investor sedang mempertaruhkan suatu nilai sekarang untuk sebuah nilai yang diharapkan pada masa 
mendatang. Dalam konteks manajemen investasi, return atau tingkat keuntungan merupakan imbalan yang diperoleh dari investasi. Return saham akan dihitung dengan menggunakan rumus sebagai berikut (Jogiyanto, 2014:206):

$$
R_{i t}=\frac{P_{i t}-P_{i t-1}}{P_{i t-1}}
$$

Keterangan:

$\mathrm{R}_{\mathrm{it}} \quad$ : Return saham i pada waktu ke $\mathrm{t}$

$\mathrm{P}_{\text {it }} \quad$ : Harga saham pada periode $\mathrm{t}$

$\mathrm{P}_{\mathrm{it}-1} \quad$ : Harga saham sebelum periode $\mathrm{t}$

\section{Variabel Independen}

Corporate Social Disclosure atau yang disingkat CSD memiliki pengertian sebagai suatu laporan perusahaan yang menyediakan informasi keuangan dan non-keuangan yang berkaitan dengan suatu interaksi organisasi dengan lingkungan fisik dan sosial, yang dinyatakan dalam laporan tahunan perusahaan atau laporan sosial yang terpisah (Guthrie \& Mathews, 1985; Hackston \& Milne, 1996). CSRD menyediakan informasi secara detail mengenai lingkungan fisik, energi, sumber daya manusia, produk, dan informasi yang berkaitan dengan komunitas.

Pengukuran CSD dalam penelitian ini akan menggunakan teknik content analysis, merupakan sebuah teknik pengumpulan data, yang meliputi mengkodefikasi informasi kuantitatif dan kualitatif yang dimasukkan berdasarkan kategori-kategori yang sesuai dengan pola yang disajikan dan dilaporkan pada informasi tersebut (Guthrie \& Abeysekera, 2006).Selanjutnya pengukuran ini akan dikategorikan berdasarkan 3 (tiga) motif perusahaan dalam melaksanakan kegiatan CSR nya, yaitu: motif keuangan (financial), motif etika (ethics), dan motif altruistik (altruistic).

\section{Pengukuran Variabel}

\section{Content Analysis}

Proses content analysis dilakukan pertama kali membaca annual report perusahaan dari halaman pertama hingga halaman terakhir sebelum bagian laporan keuangan. Selanjutnya mengidentifikasi setiap kalimat informasi dalam annual report yang merupakan pengungkapan CSD, dikaitkan dengan item-item pengungkapan CSD. Bila terdapat informasi yang mengungkapkan item dalam CSD, maka diberikan skor sesuai dengan pedoman yang ditentukan. Bila informasi tidak berhubungan dengan item pengungkapan CSR, maka informasi diabaikan dan tidak dilakukan penilaian (Gunawan et all, 2009).

\section{Pedoman untuk Penilaian Content Analysis}

Berikutnya, penilaian dalam content analysis dalam CSD, dilakukan sesuai dengan pedoman penilaian secara kuantitatif yang memberi gambaran mengenai berapa banyak informasi pengungkapan CSR (CSD) yang dilaporkan dalam laporan tahunan perusahaan. Berikut adalah komposisi penilaian dalam teknik content analysis: 
Tabel 1 -Quantitative Measurement

\begin{tabular}{|l|l|}
\hline Score & Quantity of Disclosure "how much" \\
\hline 0 & No information is disclosed in accordance with the indicators \\
1 & Sentence \\
2 & Paragraph \\
3 & 2 - 3 paragraphs \\
4 & 4 - 5 paragraphs \\
5 & $>5$ paragraphs \\
\hline
\end{tabular}

Sumber: Raar (2002), Abadi \& Gunawan (2015)

Sesuai informasi pada tabel di atas, terdapat jarak atau range nilai untuk setiap pengungkapan CSR yang dilaporkan (antara 0 -5). Penjelasan dalam pemberian skor dari tabel di atas adalah sebagai berikut:

1) Skor 0, diberikan apabila informasi tidak diungkap berdasarkan indikator pengukuran.

2) Skor 1, diberikan apabila pengungkapan dilakukan minimal dalam 1 kata atau maksimal 1 kalimat. Pengungkapan dapat juga berupa gambar, tabel atau diagram

3) Skor 2, diberikan apabila pengungkapan dilakukan minimal lebih dari 1 kalimat atau maksimal tergabung dalam bentuk 1 paragraf.

4) Skor 3, diberikan apabila pengungkapan dilakukan mencapai 2 sampai 3 paragraf.

5) Skor 4, diberikan apabila pengungkapan mencapai 4 sampai 5 paragraf

6) Skor 5, diberikan apabila pengungkapan mencapai lebih 5 paragraf.

Skor maksimum yang dapat diperoleh dalam pengukuran variabel CSD adalah 5 (lima) dari jumlah total skor pengungkapan dibagi dengan 3 item pengungkapan (motif keuangan, etika, dan altruistik). Rumus dalam pengukuran CSD dapat disusun sebagai berikut:

$$
\text { CSD score } \quad=\frac{\text { total skor pengungkapan }}{3 \text { item pengungkapan }}
$$

Penjelasan mengenai proses penilaian dalam content analysis dapat dijelaskan gambar 2 sebagai berikut:

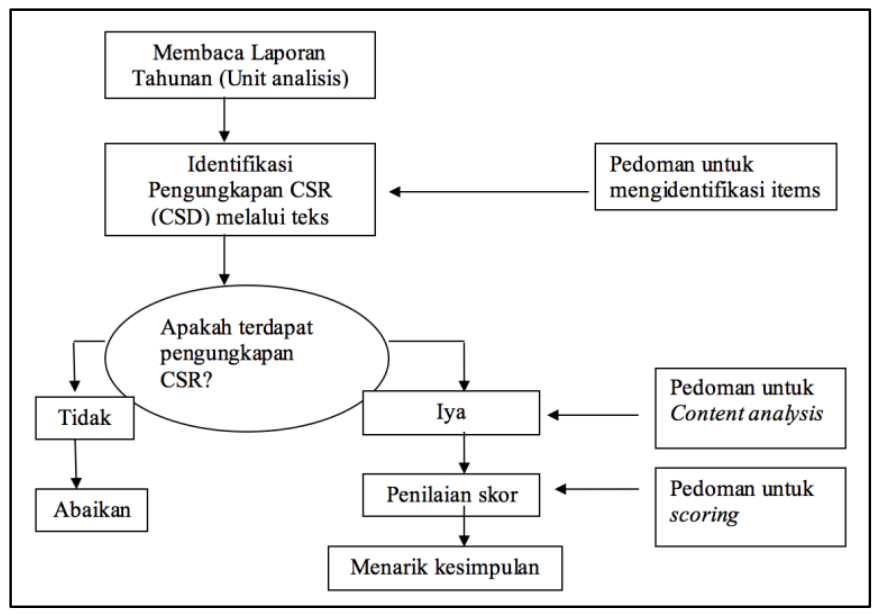

Gambar 2.Proses Penilaian Content Analysis

Sumber: Gunawan, Djajadikerta, dan Smith(2009) 


\section{Teknik Analisis Data}

Dalam penelitian ini penulis menggunakan metode analisis pengaruh, yaitu regresi linier. Merupakan salah satu alat yang dapat digunakan dalam memprediksi permintaan di masa yang akan datang dengan berdasarkan data masa lalu, atau untuk mengetahui pengaruh satu variabel bebas (independent) terhadap satu variabel tidak bebas (dependent).

Software yang digunakan untuk membantu mengolah data pada penelitian ini antara lain adalah SPSS (Statistical Package for Service Solution) for windows version, yaitu software yang berfungsi untuk menganalisis data, melakukan perhitungan statistik, baik untuk statistik parametric maupun non-parametrik dengan basis windows (Ghozali, 2013). Dalam menganalisis data dan menguji hipotesis, penulis menggunakan SPSS dengan melakukan beberapa teknik sebagai berikut: Uji Deskriptif, Uji Asumsi Klasik, Uji Koefisien Determinasi, Uji Simultan (uji F) dan Uji Parsial (uji t).

\section{HASIL PENELITIAN DAN PEMBAHASAN}

Berdasarkan sampel penelitian ditemukan 14 perusahaan yang terdaftar dalam menerima penghargaan Indonesia Most Trusted Companies Awards pada tahun 2014-2017 yang digunakan dalam pengujian statistik dengan rincian sebagai berikut:

Tabel 2 - Sampel Perusahaan

\begin{tabular}{|l|l|}
\hline No. & Nama Perusahaan \\
\hline 1 & Bank Central Asia \\
\hline 2 & Astra International \\
\hline 3 & Bank Mandiri (Persero) \\
\hline 4 & Telekomunikasi Indonesia (Persero) \\
\hline 5 & Aneka Tambang (Persero) \\
\hline 6 & Bank Negara Indonesia (BNI) \\
\hline 7 & HM Sampoerna \\
\hline 8 & Gudang Garam \\
\hline 9 & Indofood Sukses Makmur \\
\hline 10 & Unilever Indonesia \\
\hline 11 & Semen Indonesia (Persero) \\
\hline 12 & Agung Podomoro Land \\
\hline 13 & Adhi Karya (Persero) \\
\hline 14 & Garuda Indonesia (Persero) \\
\hline \multicolumn{2}{|l|}{ Sumber: Hasil Olahan } \\
\hline
\end{tabular}

Selanjutnya laporan tahunan perusahaan yang berjumlah 56 data (14 perusahaan $\mathrm{x} 4$ tahun laporan tahunan 2013-2016) dilakukan pengujian asumsi klasik untuk membuktikan bahwa sampel layak dan dapat diuji untuk menjawab hipotesis dalam penelitian ini.

\section{Hasil Uji Deskriptif}

Berikut adalah hasil untuk melihat gambaran data yang digunakan dalam penelitian ini: 
Tabel 3 - Hasil Uji Deskriptif

\begin{tabular}{|l|l|l|l|l|}
\hline & Return Saham & FM & EM & AM \\
\hline $\mathrm{N} \quad$ Valid & 49 & 49 & 49 & 49 \\
Mean &, 003796 & 4,244898 & 4,326531 & 4,551020 \\
Median &, 049300 & 5,000000 & 5,000000 & 5,000000 \\
Minimum & $-1,0000$ & 1,0000 & 2,0000 & 2,0000 \\
Maximum &, 3693 & 5,0000 & 5,0000 & 5,0000 \\
\hline
\end{tabular}

a. Multiple modes exist. The smallest value is shown

Sumber: Hasil Olahan

Berdasarkan tabel 3, diketahui jumlah data yang digunakan dalam penelitian ini adalah sebanyak 49 data, di mana terbagi dalam satu variabel dependen dan tiga variabel independen.Variabel dependen yang diproksikan menggunakan return saham memiliki nilai rata-rata 0,003796 setiap tahun atau sekitar $0,38 \%$ peningkatan nilai return saham dan memiliki nilai tengah (median) sebesar 0,049300 atas sebesar 4,9\%. Variabel ini juga memiliki nilai minimum atau penurunan hingga $-1,0000$ atau $-100 \%$ yang terjadi ada perusahaan PT Gudang Garam, Tbk pada tahun 2014 dan nilai maksimum 0,3693 atau 36,93\% kenaikan nilai return saham dari PT HM Sampoerna, Tbk.

Variabel independen CSD dengan motif keuangan (FM) memiliki nilai rata-rata 4,24 dari total maksimal sebesar 5,00 yang dimiliki sebagian besar perusahaan yang menjadi sampel ini. Sedangkan nilai 1,00 sebagai nilai minimum.Berikutnya variabel CSD dengan motif etika (EM) dan motif altruistik (AM) memiliki nilai rata-rata sebesar 4,32 dan 4,55 dari total nilai maksimal 5,00. Kedua variabel independen ini memiliki nilai minimum yang sama sebesar 2,00 .

\section{Hasil Uji Asumsi Klasik}

\section{Asumsi Normalitas}
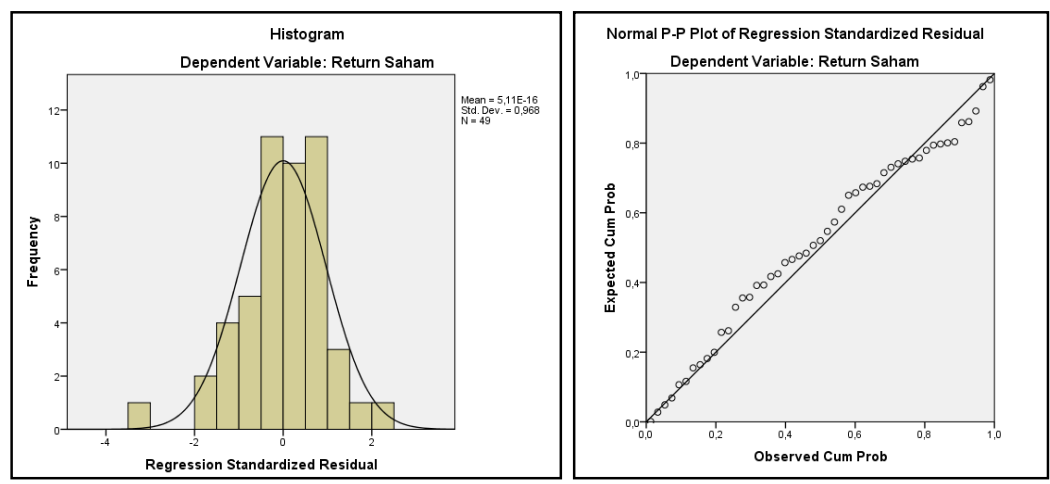

Gambar 3. Hasil Uji Asumsi Normalitas

Sumber: Hasil Olahan

Pada gambar 3membuktikan bahwa gambar histogram memberikan pola yang berbentuk mirip lonceng (bel) dan pada gambar normal P-P Plot terlihat bahwa titik-titik menyebar pada garis diagonal namun penyebarannya masih mengikuti garis diagonal tersebut. Sehingga dapat disimpulkan dari kedua gambar ini bahwa secara keseluruhan data dalam penelitian ini berdistribusi normal atau asumsi normalitas dapat diterima. 


\section{Asumsi Heteroskedastisitas}

Pada gambar 4 di bawah ini membuktikan bahwa titik-titik menyebar secara rata, tidak membentuk pola tertentu dan tersebar diantara titik nol (0) baik secara vertikal dan horizontal. Sehingga dapat disimpulkan bahwa keseluruhan data dalam penelitian ini tidak terjadi heteroskedastisitas.

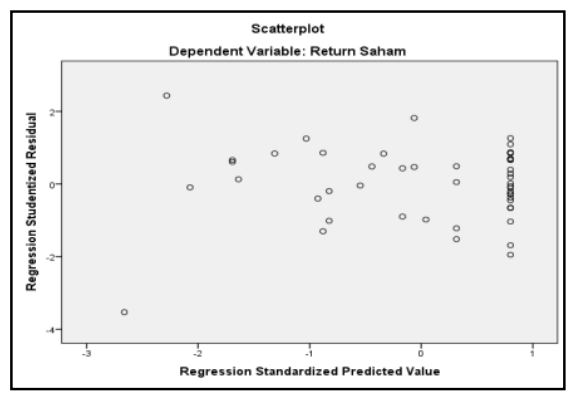

Gambar 4. Hasil Uji Asumsi Heteroskedastisitas Sumber: Hasil Olahan

\section{Asumsi Multikolinieritas}

Berikut adalah hasil pengujiannya:

\section{Tabel 4 - Hasil Uji Asumsi Multikolinieritas}

\begin{tabular}{|l|l|l|l|}
\hline \multicolumn{2}{|l|}{ Model } & \multicolumn{2}{l|}{ Collinearity Statistics } \\
\cline { 3 - 4 } & Tolerance & VIF \\
\hline 1 & (Constant) & & \\
& FM &, 610 & 1,641 \\
& EM &, 602 & 1,662 \\
& AM &, 976 & 1,024 \\
\hline
\end{tabular}

Sumber: Hasil Olahan

Pada tabel 4 telihat nilai tolerance masing-masing variabel adalah FM sebesar 0,610, EM sebesar 0,602 dan AM sebesar 0,976. Sedangkan nilai VIF variabel FM sebesar 1,641, EM sebesar 1,662, dan AM sebesar 1,024. Nilai tolerance semua variabel lebih besar dari 0,1 dan nilai VIF lebih kecil dari 10, hal ini menunjukkan bahwa dalam model regresi ini, variabel penelitian bebas dari masalah multikolinieritas.

\section{Asumsi Autokorelasi}

Tabel 5 - Hasil Uji Asumsi Autokorelasi

\begin{tabular}{|l|l|l|l|l|l|l|}
\hline \multicolumn{2}{|l|}{} & \multicolumn{2}{l|}{ Unstandardized Coefficients } & \multicolumn{2}{l|}{$\begin{array}{l}\text { Standardized } \\
\text { Coefficients }\end{array}$} & \\
\cline { 3 - 5 } Model & B & Std. Error & Beta & t & \multirow{2}{*}{ Sig. } \\
\hline 1 & (Constant) &,- 013 &, 210 & &,- 063 &, 950 \\
& FM &, 008 &, 026 &, 055 &, 291 &, 773 \\
& EM &,- 013 &, 041 &,- 061 &,- 321 &, 750 \\
& AM &, 008 &, 039 &, 031 &, 209 &, 836 \\
& RES_2 &,- 284 &, 149 &,- 284 & $-1,900$ &, 064 \\
\hline
\end{tabular}

Sumber: Hasil Olahan 
Pada tabel 5 menunjukkan nilai signifikansi Res_2 sebesar 0,064 dimana hasil ini lebih besar dari 0,05 , sehingga dapat disimpulkan bahwa data dalam penelitian ini terbebas dari autokorelasi.

\section{Hasil Pengujian Hipotesis}

\section{Hasil Uji Koefisien Determinasi $\left(\mathbf{R}^{2}\right)$}

Tampilan outputSPSSpada tabel 6, menunjukkan besarnya Adj. $R^{2}$ sebesar 0,236. Hal ini berarti $23,6 \%$ variasi return saham dapat dijelaskan melalui tiga variabel independen FM, EM dan AM, sedangkan sisanya sebesar 76,4\% (100\%-23,6\%) dijelaskan oleh variabel lain di luar model yang tidak diteliti dalam penelitian ini. Adapun variabel lain yang memengaruhi return saham yang pernah diteliti oleh Kristiana \& Sriwidodo (2012) menemukan bahwa Return on Investment (ROI), Return on Equity (ROE), Economic Value Added (EVA), \&Earning Per Share (EPS) perusahaan memiliki tingkat pengaruh sebesar 75,1\%. Penelitian lain yang dilakukan oleh Devaki (2017) menemukan bahwaDividend Payout Ratio (DPR) dan Price Earnings Ratio (PER)memiliki tingkat pengaruh sebesar 20,9\% terhadap return saham.

Tabel 6 - Uji Koefisien Determinasi $\left(\mathbf{R}^{2}\right)$

\begin{tabular}{|l|l|}
\hline Model & Adjusted R Square \\
\hline 1 &, 236 \\
\hline
\end{tabular}

Sumber: Hasil Olahan

\section{Uji Simultan (Uji F)}

Berdasarkan tabel outputSPSS pada tabel 7 di bawah ini, diperoleh nilai signifikansi F-Statistik sebesar 5,955 lebih besar dari F-Tabel sebesar 2,81 $(d f 1=3$; $d f 2=45)$, dengan nilai signifikansi sebesar 0,002 lebih kecil dari 0,05.

Tabel 7 - Uji Simultan (Uji F)

\begin{tabular}{|l|l|l|l|}
\hline \multicolumn{2}{|l|}{ Model } & F & Sig. \\
\hline 1 & $\begin{array}{l}\text { Regression } \\
\text { Residual } \\
\text { Total }\end{array}$ & 5,955 &, $002^{\mathrm{b}}$ \\
\hline
\end{tabular}

Sumber: Hasil Olahan

Oleh sebab itu dapat disimpulkan bahwa secara simultan atau bersama-sama variabel independen FM, EM, dan AM memiliki pengaruh signifikan terhadap return saham atau model tersebut layak untuk diteliti.

\section{Uji Koefisien Regresi Sederhana/ Uji Parsial (Uji t)}

Berdasarkan hasil output SPSS pada diketahui CSD berdasarkan motif keuangan memiliki nilai koefisien sebesar 0,056 dengan tingkat signifikansi sebesar 0,042. Hal ini membuktikan bahwa CSD-F memiliki pengaruh positif signifikan terhadap return saham. Selanjutnya ditemuan juga bahwa CSD berdasarkan motif etika memiliki nilai koefisien sebesar 0,049 dengan tingkat signifikansi sebesar 0,236. Hal ini membuktikan bahwa CSD-E tidak memiliki pengaruh terhadap return saham. Terakhir, terlihat bahwa CSD berdasarkan motif altruistik memiliki nilai koefisien sebesar 0,062 dengan tingkat signifikansi sebesar 0,116. Hal ini membuktikan 
bahwa CSD-A tidak memiliki pengaruh terhadap return saham. Semua hasil uji parsial dapat dilihat melalui tabel di bawah ini:

Tabel 8 - Uji Parsial (Uji t)

\begin{tabular}{|c|c|c|}
\hline \multicolumn{2}{|c|}{ Model } & Sig. \\
\hline \multirow{4}{*}{1} & (Constant) &, 001 \\
& FM &, 042 \\
& EM &, 236 \\
& AM &, 116 \\
\hline
\end{tabular}

Sumber: Hasil Olahan

\section{Hasil Pembahasan}

Berdasarkan dari hasil pengujian statistik, dapat disimpulkan sebagai berikut:

Tabel 9 - Hasil Pengujian Hipotesis

\begin{tabular}{|c|l|c|c|}
\hline \multicolumn{2}{|c|}{ Hipotesis } & Hasil & Nilai Sig. \\
\hline H1 & $\begin{array}{l}\text { Terdapat pengaruh CSD berdasarkan motif } \\
\text { Keuangan (CSD-F) terhadap Corporate Financial } \\
\text { Performance - Market Based Measure }\end{array}$ & Diterima & 0,042 \\
\hline H2 & $\begin{array}{l}\text { Terdapat pengaruh CSD berdasarkan motif etika } \\
\text { (CSD-E) terhadap Corporate Financial } \\
\text { Performance-Market Based Measure. }\end{array}$ & Ditolak & 0,236 \\
\hline H3 & $\begin{array}{l}\text { Terdapat pengaruh CSD berdasarkan motif } \\
\text { altruistik (CSD-A) terhadap Corporate Financial } \\
\text { Performance-Market Based Measure. }\end{array}$ & Ditolak & 0,116 \\
\hline
\end{tabular}

Sumber: Hasil Olahan

Pada hipotesis pertama $(\mathrm{H} 1)$, hasil penelitian ini berbanding terbalik dengan penelitian Pratiwi (2015) yang menjelaskan bahwa motif keuangan tidak memiliki pengaruh signifikan terhadap $\mathrm{CFP}$-Accounting Based Measure.Hasil penelitian ini sejalan dengan legitimacy theory dimana salah satu tujuan perusahaan dalam melakukan CSR adalah untuk meningkatkan kepercayaan masyarakat terhadap kegiatan operasional yang dijalani oleh perusahaan tersebut. Terdapat manfaat yang didapat oleh perusahaan ketika melaksanan CSR sebagaimana mestinya, seperti meningkatkan citra perusahaan dimana perusahaan dipandang memiliki nilai kepedulian terhadap masyarakat. Melalui CSR, perusahaan juga mampu membuka akses investasi dan tambahan pembiayaan bagi perusahaan. Perusahaan yang melakukan CSR memiliki magnet tersendiri untuk menarik minat investor dalam menanamkan modalnya. Pada akhirnya, perusahaan yang secara rutin melakukan kegiatan CSR yang sesuai dengan bisnis utamanya, maka permintaan saham perusahaan di pasar akan meningkat dan nantinya akan mampu meningkatkan harga saham perusahaan tersebut.

Pada hipotesis kedua (H2), Hasil penelitian ini berbanding terbalik dengan penelitian Pratiwi (2015) yang menjelaskan bahwa motif etika memiliki pengaruh signifikan terhadap CFP Accounting Based Measure.Penjelasan pada hasil penelitian ini tidak sejalan dengan legitimacy theory, namun sejalan dengan konsep triple bottom line dimana perusahaan harus memiliki 


\section{National Conference of Creative Industry: \\ Sustainable Tourism Industry for Economic Development}

Universitas Bunda Mulia, Jakarta, 5-6 September 2018

e-ISSN No: 2622 - 7436

kepedulian terhadap kesejahateraan manusia serta kesejahteraan lingkungan tempat dimana perusahaan beroperasi. Sehingga program CSR yang dilakukan perusahaan seperti pemberian beasiswa, pembangunan dan pengembangan sarana pendidikan, penguatan kapasitas ekonomi lokal atau bahkan perlindungan sosial bagi warga setempat adalah kewajiban perusahaan. Mengingat bahwa hal-hal tersebut merupakan hal yang wajib dilakukan oleh perusahaan, maka fokus investor saat ini telah berubah yang mana investor lebih tertarik untuk berinvestasi jika dan hanya jika investasi tersebut mampu memberikan keuntungan atau timbal balik atas dana yang diinvestasikan. Hal ini mengakibatkan bahwa CSR berdasarkan etika tidak mampu memberikan pengaruh terhadap return saham.

Sedangkan pada hipotesis ketiga (H3), hasil penelitian ini sejalan hasil dengan penelitian Pratiwi (2015) yang menjelaskan bahwa motif altruistik memang tidak memiliki pengaruh signifikan terhadap CFP - Accounting Based Measure. Hasil ini juga didukung oleh penelitian Breliastiti (2014) dengan argumentasi bahwa Pasar akan berekasi negatif saat mengetahui bahwa kegiatan sosial yang dilakukan oleh perusahaan berdasarkan motif altruistik. Hal ini mungkin disebabkan karena para investor di Indonesia semata-mata masih berinvestasi dengan harapan return yang tinggi dan kurang berkenan bila perusahaan mengeluarkan bantuan sosial tanpa pamrih. Penjelasan pada hasil penelitian ini tidak sejalan dengan legitimacy theory, hal ini dikarenakan kegiatan CSR altruistik yang dilakukan perusahaan selain untuk kesejahteraan lingkungan namun jauh melampaui itu. Ketidakmampuan CSR-A dalam memengaruhi return saham dikarenakan CSR-A masih mengandung berbagai kontroversi yang mengundang perdebatan di kalangan akademisi maupun di kalangan pebisnis sebagai pihak yang menjalankan program tersebut. Selain itu, tantangan global berkata bahwa perusahaan tidak membutuhkan loyalitas pelanggan untuk meningkatkan market share yang tujuan akhirnya adalah peningkatan profit dengan cara anggaran tersendiri atau terpisah dari anggaran beban operasional. Dengan kata lain, perusahaan hanya melakukan anggaran beban yang mencakup dua elemen sekaligus, yaitu elemen kebutuhan bisnis dan kegiatan sosial. Sehingga investor menilai bahwa pendapatan perusahaan dapat dipertahankan, beban-beban dapat dikurangi dan akan meningkatkan profit perusahaan tanpa melakukan CSR-A.

\section{KESIMPULAN DAN IMPLIKASI}

Berdasarkan hasil pembahasan di atas, maka dapat disimpulkan bahwa:

1. Hipotesis pertama diterima, bahwa terdapat pengaruh CSD berdasarkan motif Keuangan (CSD-F) terhadap Corporate Financial Performance - Market Based Measure. Ini sejalan dengan teori legitimasi, tetapi tidak sejalan dengan hasil penelitian Pratiwi pada tahun 2015.

2. Hipotesis kedua ditolak, bahwa tidak terdapat bukti yang cukup mengenai pengaruh CSD berdasarkan motif Etika (CSD-E) terhadap Corporate Financial Performance - Market Based Measure. Ini sejalan dengan konsep triple bottom line, tetapi tidak sejalan dengan hasil penelitian Pratiwi pada tahun 2015.

3. Hipotesis ketiga ditolak, bahwa tidak terdapat bukti yang cukup mengenai pengaruh CSD berdasarkan motif altruistik (CSD-A) terhadap Corporate Financial Performance - Market Based Measure. Ini sejalan dengan hasil penelitian Breliastiti (2014) dan Pratiwi (2015).

Hasil penelitian ini pun diharapkan dapat memberikan manfaat bagi perusahaan go public, nonpublic, atau yang akan go public, untuk memperhatikan kebijakan dan implementasi terhadap tata kelola perusahaan dan kualitas pengungkapan tanggung jawab sosial perusahaan yang dilaporkan dalam laporan tahunan perusahaan. Selain itu perusahaan dapat mengubah 
perspektif bahwa investasi CSR bukan hanya sebagai beban di tahun sekarang, tetapi akan membawa manfaat pada waktu yang akan datang dengan kegiatan CSR perusahaan yang tepat. Kegiatan yang dilakukan pun dapat bervariasi dengan memperhatikan setiap motif keuangan, etika, dan altruistik agar seimbang dan merata dirasakan seluruh masyarakat. Sehingga bila seluruh informasi keuangan dan non keuangan (salah satunya mengenai corporate social responsibilitydisclosure) dalam laporan perusahaan diawasi dan dinilai secara detail, maka perusahaan dapat memperoleh good image dan trust publik, yang menjadikan keunggulan kompetitif perusahaan.

Hasil penelitian ini juga diharapkan dapat memberikan manfaat bagi investor atau calon investor sebagai bahan referensi dan bahan analisa dalam mengevaluasi kinerja perusahaan, tidak hanya dari perspektif keuangan, tetapi juga dari perspektif non-keuangan, salah satunya adalah pengungkapan corporate social responsibility (CSD) perusahaan, dalam rangka menentukan keputusan untuk mengivestasi. Selain itu investor juga dapat bertindak sebagai pengawas bagi perusahaan yang berkomitmen menjalankan tata kelola perusahaan yang baik dan pengungkapan corporate social responsibility, dilakukan setiap tahunnya dan tepat sasaran.

Penelitian selanjutnya juga diharapkan menjadi lebih berkembang lagi dengan sampel dan metode penelitian yang lebih beragam dan kompleks sehingga menambah referensi pengetahuan mengenai motif CSR dalam perusahaan dan pengaruhnya dengan kinerja perusahaan dari sisi internal maupun eksternal.

\section{DAFTAR PUSTAKA}

Breliastiti, Ririn, dkk (2014). Pengaruh Motif CSR terhadap Kegiatan CSR dan Dampaknya terhadap Kinerja Keuangan Perusahaan Pertambangan di Indonesia. Jurnal Akuntansi dan Bisnis. Universitas Bunda Mulia.

Chen, J. C., Patten, D. M., \& Roberts, R. W. (2008). Corporate Charitable Contributions: A Corporate Social Performance or Legitimacy Strategy? Journal of Business Ethics, 82 (1), 131-144.

Deegan, C., Rankin, C., \& Tobin, J. (2002). An Examination of The Corporate Social and Environmental Disclosures BHP from1983-1997: A Test of Legitimacy Theory. Accounting, Auditing \& Accountability Journal, 15 (3), 312-343.

Deegan, C., Rankin, M., \& Voght, P. (2000). Firms Disclosure Reactions to Major Social Incidents: Australian Evidence.Accounting Forum, 24 (1), 101-130.

Ghozali, Imam. (2013). Aplikasi Analisis Multivariate dengan Program IBM SPSS 21 Update PLS Regresi. Badan Penerbit Universitas Diponegoro. Semarang.

Graafland, Johan (2012), Motive For Social Responsibility,De Economist Volume 160, issue 4 p.377-396.

Gray, R., Owen, D., \& Adams, C. (1996). Accounting and Accountability: Social and Environmental Accounting in a Changing World. Hemel Hempstead: Prentice-Hall.

Gunawan, Juniati, Djajadikerta, Hadrian, \& Smith, Malcolm. (2009). an Examination of Corporate Social Disclosures in the Annual Reports of Indonesian Listed Companies. 
Isnalita \& I Made Narsa. (2017) CSR Disclosure, Customer Loyalty, and Firm Values (Study at Mining Company Listed in Indonesia Stock Exchange).Asian Journal of Accounting Research Vol. 2 Issue: 2, pp.8-14, https://doi.org/10.1108/AJAR-2017$\underline{02-02-B 002}$

Jogiyanto, (2014), Teori Portofolio dan Analisis Investasi, Yogyakarta: BPFE-UGM

Khan, A., Muttakin, M. B., \& Siddiqui, J. (2013). Corporate Governance and Corporate Social Responsibility Disclosure: Evidence from an Emerging Economy. Journal of Business Ethics, 114, 207-223.

Khlif, H., Guidara, A., \& Souissi, M. (2015). Corporate Social and Environmental Disclosure and Corporate Performance. Journal of Accounting in Emerging Economies, 5 (1), 51-69.

Lantos, Geoffrey P. (2001). The Ethicality of Altruistic Corporate Social Responsibility. Stonehill College.

Legiman, Fachreza Muhammad, et al.,(2015), Faktor-faktor yang mempengaruhi return saham pada perusahaan agroindustry yang terdaftar di Bursa Efek Indonesia periode 20092012,Jurnal EMBA, vol.3 No.3.

Pratiwi, Devica. (2015). Pengaruh Biaya Corporate Social Responsibility (CSR Cost) Berdasarkan Motif Keuangan, Motif Etika, dan Motif Altruistik Terhadap Corporate Social Performance. Jurnal Akuntansi dan Bisnis. Universitas Bunda Mulia.

Raar, J. (2002). Environmental Initiative: towards triple bottom line reporting. Corporate Communication, An International Journal, 7 (3), 166-83.

Radyati, M. R. (2014). Sustainable Business dan Corporate Social Responsibility (CSR). Jakarta: CECT Trisakti University Indonesia.

Waddock, S. A., \& Graves, S. B. (1997). The Corporate Social Performance - Financial Performance Link. Strategic Management Journal, 18 (4), 303-319.

Wang, K. T., \& Li, D. (2016). Market Reactions to the First-Time Disclosure of Corporate Social Responsibility Reports: Evidence from China. Journal of Business Ethics, 138, 661-682. 